\title{
Vloga znanja v politični resocializaciji
}

\author{
Bogomir Novak
}

\section{Obstaja več razlogov, zaradi katerih se vprašanje znanja pri aktivnem prilagajanju odraslih na razmere $v$ tranziciji zastavlja izrazito dvosmiselno.}

Prvi razlog je v tem, da je tranzicija, ki je nastala zaradi zgodovinskega krča in stresa, bolj iracionalni vzgib kot pa plod temeljite analize socialnih vzrokov in posledic pomanjkljivosti $\mathrm{z}$ polpreteklega obdobja. V boju proti zunanjim sovražnikom je sicer socializem izgubil svojo zgodovinsko nujnost in je postal utopija, kulturna dihotomija »nas in drugih « pa ostaja.

Drugi razlog je v tem, da je učenje za demokracijo, posebej za stabilno demokracijo, učenje za samostojnost v državi, v kateri se nacionalni subjekt konstituira. Ni mogoče strogo objektivno ugotoviti, ali smo Slovenci (bili) zgodovinski subjekt ali ne. Ta občutek je odvisen od nihanja med potrpežljivim pogumom oziroma upanjem in strahom, ki ga imamo v odnosu do zastavljenih nalog. Če se nam zdi večja kakovost demokracije nedosegljiva, je to izraz strahu, da nas lahko tako imenovani objektivni dejavniki, okoliščine uničijo. Nasprotno pa so v znanju kot sestavini nacionalne identitete možnosti za samoohranitev.

Tretji razlog je $\mathrm{v}$ heteronogenosti kategorij odrasli in mladina. To pomeni, da se je ost konflikta prenesla s starostne razlike med generacijami na polarizacijo interesov v njih. Obstaja pasivna in aktivna mladina in pasivni in aktivni odrasli. Odrasli smo šolani $\mathrm{v}$ uporništvu zoper hlapčevanje, od kmečkih uporov do socialistične revolucije, sedaj pa se srečujemo z možnostjo partnerskega sodelovanja $v$ soodvisnem svetu. Toda ta tretja možnost je uresničljiva le tedaj, če prerastemo gospodovanje $\mathrm{z}$ vedenjem hlapca v avtokratski kulturi. Tudi danes so še prevladujoče pasivne sestavine podložniške kulture, na primer z udeležbo na volitvah in s stališčem, da je politika stvar politikov. Veliko je še pričakovanj, da bo država poskrbela za reševanje vseh družbenih problemov. Del mladine bolj zaupa politikom in je bolj optimističen glede vloge strank. Obstaja odprto vprašanje, ali se Slovenija približuje vzorcem političnega dihotomiziranja na pasivne množice, v katerih se zbira energija nekontroliranih socialnih in političnih konfliktov, ter osamosvojitveno elito, ki skrbi za sebične interese in zanemarja upravljanje dejanskih konfliktov (Hafner-Fink, 1993:30-31).

Naslednji razlog je v ambivalentni (zlo)rabi znanja. Vsaka razvita družba temelji na učinkovitosti znanja. Ne smemo pozabiti, da so razvite družbe, ki so nam vzor, v rastoči kompleksnosti tudi čedalje bolj ranljive in tvegane. Te družbe se morajo $\mathrm{z}$ novim znanjem braniti pred enostranskimi in negativnimi učinki dosedanje aplikacije znanja za spreminjanje okolja. Razvoj znanja le postopno nakazuje iskanje dinamičnega ravnotežja med nasprotji, pa tudi kvaliteta demokracije se kaže v balansiranju med nasprotujočimi si interesi.

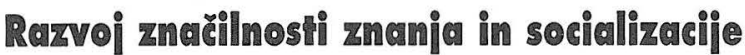

Gre za vprašanje vrednotenja znanja. Razvoj spoznanja je potekal zgodovinsko antitetično, protislovno, ne le pri eni vrsti zna- nja, temveč tudi med vrstami. Poznamo zares ali navidez izključujoče se religiozne, filozofske in znanstvene teorije. Pojmovno, interpretativno znanje je $v$ mreži informacijskih povezav. Novo znanje dobi posplošeno obliko $\mathrm{v}$ znanosti zaradi primerljivosti spoznanj (npr. valovno-korpuskularna teorija svetlobe), v šoli pa zaradi transferja učenja. Čim več vemo, tem bolj se zavedamo, da razvoj znanosti relativira pomen empiričnega znanja in negira antično predstavo o dokončnem znanju. Čim hitreje nastaja novo znanje, tem hitreje zastareva staro. Zato se tudi šolski kurikuli vedno spreminjajo in skušajo poenotiti novo nastalo znanje. Razumevanje znanja kot količine izhaja iz cilja proizvodnje, ki je v količini produktov. Akumulaciji kapitala ustreza akumulacija znanja. Tudi kulturni, človeški kapital za svoj obtok potrebuje znanje. Znanje je hkrati s sposobnostmi sestavina proizvajalnih sil in je pogoj in posledica prestrukturiranja dela, ker gre za bolj kvalificirano delovno silo. S postavljanjem različnih tipov osebnosti se je $\mathrm{v}$ raznih obdobjih spreminjalo tudi vrednotenje znanja $\mathrm{v}$ šoli in zunaj nje. $\mathrm{V}$ starem veku je bila osnovna vrednota religiozno znanje, danes pa je znanstveno znanje, ki po eni strani nastaja $\mathrm{z}$ raziskovanjem, po drugi pa se predeluje za didaktične namene poučevanja.

Razlikujemo med znanjem, ki je usmerjeno k neživim stvarem in znanjem, ki je usmerjeno k življenju, med razumevajočim in razlagajočim, družboslovnim in naravoslovnim znanjem. V šoli se prepletata obe vrsti znanja, v družini, ki ni več ekonomska, temveč je le konzumna celica, pa naj bi prevladovalo odnosno znanje o svetu življenja. Socializacija otrok in odraslih poteka prek opredmetenega minulega dela/dejavnosti, znanja in (kulturnega) kapitala. Družina in šola, ki sta usmerjeni v prihodnost, naj bi razvijali predvsem znanje o organski povezanosti življenja, ki je znanje »mehkega vala«. Politična socializacija je fragmentirana ali celovita glede na celovito ali fragmentirano znanje in glede na strankarsko deljeno ali integralno politiko.

Sprememba vrednotnih vedenjskih (behavioralnih) obrazcev znanja se dogaja $\mathrm{v}$ procesu de- in resocializiranja. Odrasli so $\mathrm{v}$ naslovu tega prispevka posebej omenjeni kot posebna kategorija, ker jo še vedno razumemo kot večinsko najbolj aktiven del prebivalstva, ki ima v primerjavi z otroki in mladino največ akumuliranega znanja. Ta teza ni več samoumevna zaradi naglega staranja odraslih v primerjavi s slabo nataliteto in učinkovitejše prenove šolskih kurikulov. Zato odrasli nismo več reprezentanti družbe v celoti. Odrasli hkrati s socializiranjem otrok $\mathrm{z}$ uporabo obrazcev znanja de-in resocializirajo sebe. V novem veku se namesto dominacije religije (teokracija) politika pojavlja kot usoda, vsemogočna subjektivna sila (politokracija). Politika v tranziciji sicer ne določa več neposredno vsake značilnosti vsakdanjega življenja tako kot v socializmu, posredno pa ga še vedno.

Izobraženi odrasli hitreje kot otroci povezujejo staro znanje $\mathrm{z}$ 
novim prek generalizacije in transferja ${ }^{1}$ učenja. Odrasli se sicer zavedajo pomena radovednosti kot motiva pridobivanja novega znanja, vendar se bolj kot oni zavedamo njegove objektivne in subjektivne nujnosti. Čim več starega znanja imamo, tem laže pridobivamo novo znanje, ki ga zahtevajo nove okoliščine.

Nekatere družine socialno učijo, da se mora posameznik prilagoditi družbi, druge pa, da se mora upirati, tretje zagovarjajo skupinsko odgovornost. V vsaki družini se njeni člani neformalno učijo, kako se je treba spoprijemati z zunanjim svetom, uspešno sodelovati in kako vrednotiti življenje. Večina družin je naravnanih $\mathrm{k}$ materialnim in prestižnim (dionizičnim) vrednotam, in ne $\mathrm{k}$ apolonsko miroljubnim.

Analiza avtokratskih osebnosti, ki jim manjka samozavesti in (samo)zaupanja kaže, da se gibljejo od tistih, s katerimi bi lahko sodelovali. Sovražnost zmanjšuje samospoštovanje in sposobnost skupnega reševanja problemov. Prav majhna, podložniško avtokratska kultura vodi do politike kot boja za oblast, demokratična pa vodi v skrajni posledici do politike skupnosti (nem. Gemeinschaft nasproti Gesellschaft). Samorealizacija je možna le pri osebnostih, ki so v odnosu druga do druge moralni cilj in imajo bogato kulturo v skupnosti za razliko od instrumentalne družbe, v kateri uporabljajo drug drugega za sredstvo.

Za predmoderne družbe zadošča zaprto znanje in stereotipna socializacija. Z rastjo potreb se širi edukacija na vsa življenjska posameznikova obdobja, ni le rezultat eksplozije znanja, temveč je še prej posledica diferenciacije potreb na materialne, postmaterialne in informacijske. Kapitalizem skuša reducirati neproizvodni čas in spremeniti učenje v blago. Šele novoveška subjektiviteta je temelj znanja, spoznanja in izkušenj. V renesansi je biti človek pomenilo biti izobražen. Univerzalno znanje je nasprotovalo fevdalni stanovski, lokalni, samovoljni omejenosti. Univerzalno znanje ima najsplošnejšo metodološko vrednost za umetnost problematiziranja in razumevanja tega sveta.

Že v antiki so razpravljali o tem, ali je mogoče obvladovati ljudi z znanjem in o pomenu javnih razprav. Etično znanje je bilo oblika razumskega nadzora nad čuti, strastmi, nagoni in razbrzdanostjo. Njegov cilj je bila zmerna zadržanost. Empirično znanje se ni čezmerno širilo. V antiki so prvič, vendar drugače kot danes, skušali najti in obdržati ravnotežje med znanjem za obvladovanje človekove notranje narave (zadržanost) in znanjem za obvladovanje zunanje narave.

Že od Platona dalje upravičevanje znanja ni ločljivo od upravičevanja (oziroma razglasitve zakona za normo) zakonodajalca. $\mathrm{Za}$ Platona je znanje rezultat napornega prehoda iz teme (votline) na svetlobo. Za Aristotela je vsako znanje označevalno (apofantično), po tem, da se nanaša na stvari, kakršne so in je glede na to (ne)ustreznost resnično ali zmotno. Danes velja, da je določen izraz znanstven izraz takrat, kadar pripada jeziku, ki ga strokovnjaki ocenijo kot ustreznega. Kadar prevladuje pripovedno znanje pred znanstvenim, to pomeni, da miti/zgodbe določajo merila kompetence, kaj se lahko reče in dela v kulturi. Znanstveno znanje je za razliko od predznanstvenega posredovano in dokazljivo. Danes gre v nekem smislu za povratek k mitu/pripovedi, ki se imenuje »metanaracija $\ll$ (Lyothard).

$\mathrm{V}$ novem veku postane prav instrumentalno, praktično znanje vrednota proti srednjeveškemu mračnjaštvu. Znanje, ki ga človek pridobiva v socialnem učenju, postane razvojno. Šlo je za razvoj delovnih sposobnosti, ne pa še avtonomne osebnosti same. Zato

\footnotetext{
${ }^{1}$ Beseda transfer je sestavljena iz besed trans - prek in fero, ki ima $\mathrm{v}$ starogrškem (in latinskem) jeziku pomeni: nosim, prenašam, odnašam, odmikam, dobavljam. Glej Senc, Stjepan (1988): Grčko hrvatski rječnik za škole. Zagreb, Naprijed, str. 975-976.
}

še danes premalo poznamo osvobajajočo, formativno-razvojno osebnostno moč znanja. Zaradi različnih razlogov, kot so diktatura nespremenjenega stanja in prepričanja $\mathrm{v}$ pravilnost lastnih ali prevzetih stališč, diktature nad potrebami po komunikaciji in dialogu, še vedno obstajajo odpori proti znanju, ki omogoča kritično mišljenje.

Poznamo različne filozofske teorije o izvoru in merilu spoznanja, od empirizma do racionalizma. Te teorije imajo $\mathrm{v}$ samem vzgojnoizobraževalnem procesu praktičen pomen. Intelektualizem v šoli postavlja racionalistično spoznavno teorijo, ki izhaja iz stališča, da je vse spoznanje že v razumu, šolski pozitivizem, po katerem je učenec le polnilnik podatkov, pa korenini v empirizmu. Naša interakcija s predmetnim svetom, z drugimi ljudmi in $\mathrm{s}$ samim seboj poteka na osnovi spremenljivega znanja in njegovih omejitev. Znanje je sicer načelno neomejeno, v konkretnih vzajemnih odnosih pa je končno, ker je pogojeno $\mathrm{z}$ našimi interesi in interesi drugih, prostorsko-časovnimi omejitvami kot določenimi pogoji medsebojnega komuniciranja.

Prehodne oblike med znanjem in neznanjem nastajajo $v$ razmerju med znati (know) in verjeti (believe). Še vedno več verjamemo, kot vemo. To se pokaže zlasti pri sinteznih oblikah znanja, analitično znanje pa je videti trdnejše. Znanje je daljnoročna investicija le takrat, kadar ima metodološko vrednost po načelu »vedeti kako«. Ker znanje nastaja zaradi reševanja praktičnih problemov, je interes znanja interes obvladovanja prihodnosti. Znano je, da bo prihodnost imel tisti, ki jo bo obvladal, obvladal pa jo bo tisti, ki razpolaga $\mathrm{z}$ inovativnimi idejami že danes.

Subjekt političnega odločanja je tisti, ki zna pri urejanju družbenih zadev uporabljati znanje. Politična socializacija, ki ne doseže tega cilja, ni socializacija za participativno demokracijo. Na nižji stopnji politične kulture je danes večina odraslih še objekt politike. Eden izmed razlogov za nižjo stopnjo politične kulture je, da je večji del družboslovnega znanja o socialistični ureditvi s spremembo političnega sistema postalo neaktualno in ima le še vrednost zgodovinskega spomina. V tranziciji sta se delno spremenili metoda pri analizi in načinu reševanja družbenih problemov.

Postmoderno znanje ni samo sredstvo moči, ker izostruje našo senzibilnost za razlike. Kot sredstvo moči ima znanje obliko poveljevanja v vojski, šoli, cerkvi in državni upravi. Kot se je človek doslej potegoval za osvajanje prostora, se odslej poteguje za obvladovanje informacij. Po svoji obliki je znanje informacijsko blago $\mathrm{v}$ boju za oblast. Znanje je imelo $\mathrm{v}$ antiki ${ }^{2}$ predvsem teoretičen, v novem veku pa ima predvsem praktično-tehnološki pomen. Vendar pa izguba teoretske ravni znanja pomeni daljnoročno izgubo uporabne vrednosti, ker gre za izgubo teoretičnosti (videnja nevidnih strani) prakse.

Znanstveno znanje ni celovito, temveč je parcializirano, specializirano in je v sporu s pripovednim. Tekmovalnost znanosti s poprejšnjimi vrstami znanja, kakršni sta religija filozofija, je v 20. stoletju razvidna iz skrajnosti scientizma oziroma (neo)pozitivizma.

Za to filozofijo znanosti so pomembna samo dejstva po zgledu naravoslovne znanosti. Pozitivistična znanost je hotela izpodriniti religiozno in metafizično znanje, vendar ji to ni uspelo. Tudi znanstveno spoznanje ima svoje razvojne meje. Danes verjame-

\footnotetext{
${ }^{2}$ Že iz antike vemo, da je znanje hkrati o enem ali o razdvojenem in mnogoterem. V prihodnosti pričakujemo večji pomen celovitega znanja o enem, ki izvira iz boga ali duha in manjši pomen parcializiranega - specializiranega znanja, ki je omejen na čutno-razumske kategorije. Etimologija izraza znanje (indoevropsko veid - videti, gr. ideia, eidos, lat. videre) kaže na uvid, intuicijo. V finskem jeziku pomeni tieto poznati pot, pomagati priti tja. V nemški etimologiji sta soodnosna termina Wissen in Gewissensein.
} 
mo, da človek ne bo nikoli vsega spoznal in obvladal, čeprav so meje med obvladljivim in neobvladljivim premične, tako kot so med spoznavnim in nespoznavnim.

Moderna doba razvija samo sebi nasprotujočo si in v zunanji svet usmerjeno obliko znanja. Novodobni človek je bil prepričan, da sta njegovo spoznavanje in vesolje neskončna. Moderna oblika znanja je opredeljena $\mathrm{z}$ voljo po spreminjanju in obvladovanju sveta. Ta težnja vodi $v$ frustracije in konflikte, ki pa so spodbuda za več znanja. Govorimo o akumulaciji kapitala, dela, znanja in tehnike do »vojne zvezd« in nič manj grozljivih lokalnih vojn. V tem je samouničujoča postavitev modernega človeka »na glavo«. Prav zato, ker človek ni niti astronomsko niti biološko in psihološko v središču vesolja, je vedno znova postavljen pred nalogo, da poišče svoj tem(p)elj. Tudi to je lahko »Sizifovo delo«. Človek, ki je zaradi preseganja dosedanjih meja $\mathrm{v}$ skrajni posledici izgubil svoje središče in istovetnost $\mathrm{v}$ neonaci(onali)zmih in postmodernih narcizmih, proizvaja ekscentrično znanost, ki se odslikava v decentralizaciji subjekta - jaza, družine in šole. Nasproti tem dezintegracijskim procesom heterogene inkulturacije poteka proces integracije.

Novo znanje raste eksponentno. $\mathrm{Z}$ neurejenim povečevanjem količine informacij se zmanjšuje njihova informacijska vsebina oziroma vrednost. Informatizirano znanje je blago, ki pa ni vsem enako dostopno. Čim višji zaslužek obeta uporaba znanstvenih rezultatov, tem teže je priti do takšnega znanja. Prehod v nov informacijski sistem omogočajo nove metode in tehnike. Faktografske in bibliografske baze podatkov so izhodišče za baze znanja in ekspertne sisteme (npr. simulacija, uvajanje umetne inteligence).

Majhne dežele, kot je naša, potrebujejo podatke o raznolikih možnostih uporabe informacij. Od nekdaj so raziskovalci skušali urejati podatke $v$ takšne skupine, ki jim omogočajo dobiti pregled nad razmerji med njimi. Informatizacija dolgoročno vpliva na večjo kakovost izdelkov, pa tudi na vzgojo in izobraževanje. Največjo napovedno moč imajo vzorci, matrike znanja, kadar jih povezujemo v integrirane sisteme - zemljevide znanja, ki omogočajo »vedeti kako«. Informacijski sistem razvršča znanje in omogoča selekcijo ter orientacijo raziskovalnega dela.

Posamezniki si znanje o razvoju človeške vrste pridobivajo zavestno in podzavestno, z učenjem. Strategije učenja so strategije prisvajanje novega znanja, reproduciranja starega in integracije starega v novo. Vsak (odrasli) učenec bi si moral zaradi večje motivacije in aktivnejšega pristopa izdelati načrt učenja in vedeti, zaradi katerih ciljev se uči. Učitelj pa bi moral te procese spodbujati. Zlasti učitelji bi morali pri učencih spodbujati pridobivanje novega znanja in sposobnosti na osnovi starega. Ozkost posredovanega strokovno-predmetnega znanja se pokaže v tem, da učitelj pogosto še danes ne ve tega, kar bi moral vedeti kot dober učitelj manager . ${ }^{3}$

Znanje se zgodovinsko razvija od splošnega k specialnemu ter operativnemu in nasprotno. Tako je to, kar je nekoč spadalo v filozofijo, danes že v posebnih vedah, nasprotno pa filozofija preučuje nekatera mejna področja posebnih ved. Del specialnih, tehničnih, znanj je že splošnih. Sistem znanj razumemo kot možnost dostopa do vsebin (jeziki), možnost manipuliranja z vsebinami (logika, matematika, statistika), možnost spoznavanja novih vsebin (metodologija znanosti), možnost uporabe (uporabne vede) ter vsebine same (taksonomije). $\mathrm{Na}$ vprašanje, koliko je pomanjkanje surovin nadomestljivo $\mathrm{z}$ neizčrpnim in nenadomestljivim virom človeške pameti in znanja, nam bo vsaj delno odgovoril razvoj informacijske tehnologije.

\footnotetext{
${ }^{3}$ Več o kakovosti vodenja glej Glasser William (1995): Kontrolna teorija za managerje. Radovljica. Regionalni izobraževalni center.
}

Poznanstvenje sveta ne gre več samo v smeri ustvarjanja umetnega sveta, temveč tudi v smeri ohranjanja sveta in kulture življenja. Ne gre več le za ločevanje od tradicije, ki je zaradi širjenja norm delovanja industrijske družbe izgubila svojo spontanost, marveč tudi za povezovanje $\mathrm{z}$ njo zaradi zaščite naravnega okolja. Brez sveta življenja tudi svet sistema ne bo mogel obstajati, čeprav se je doslej razvijal v njegovo škodo. To dejstvo bi morala upoštevati integrativna politika. Vdelati pa bi ga bilo treba tudi $\mathrm{v}$ politično socializacijo.

Znotraj znanja odkrivamo strukturna razlikovanja: ne le moderni epistemološki rezi, temveč tudi postmoderne vezi, ne le gotovo, definitorno, pogojno znanje, marveč tudi negotovo, nedoločljivo od zunaj in samorefleksivno od znotraj, apriorno. S širjenjem meja znanja se zamegljuje opredelitev tega, kar je nekoč veljalo za pravo oziroma konvencionalno znanje. Pravo znanje je v vsakem obdobju nekaj drugega. Tristopenjskega razvoja znanja, ki obsega začetno, procesno in končno razvojno fazo, ni opisal le Lyothard, temveč sta jo opisala pred njim že Hegel in Comte. Aktualno znanje je med spominom in anticipacijo novega.

Dobro poučevanje in učenje ni mogoče brez razlikovanja različnih vrst znanja. O pravem, resničnem znanju lahko govorimo pogojno ali brezpogojno; pomeni negacijo navideznega, ne glede na religijo, filozofijo ali posebne znanstvene discipline. Pravo znanje je v religiji razodeta resnica, v znanosti pa je dokazana, preskušena, potrjena resnica, ki je ni mogoče falsificirati - ovreči s sedanjo metodo znanosti. V prvem primeru znanje vključuje tistega, ki ve, v drugem pa je to objektivno, vrednotno nevtralno znanje o predmetu, ki je neodvisen od nas. Razlikujemo med pojmovnim znanjem in znanjem o pojmu, kakor se je razvilo $v$ formalni logiki in spoznavni teoriji.

Šele spoznanje, da je socialno delo nenadomestljivo in ima zato prihodnost, bo spodbudila razvoj odnosnega znanja $\mathrm{v} 21$. stoletju, poleg rabnega in menjalnega znanja. Po drugi strani pa »civilizacija kokakole in iluzij« poraja toliko narcisoidnosti in psihopatologije, da se bo to znanje moralo humanizirati, če bodo ljudje hoteli preživeti. Pospešen razvoj konkurence zaradi naše nepripravljenosti na vedno nove tehnologije že od vrtca najprej povzroča strese, ki so težko odpravljivi. Zaradi praktičnih potreb po obvladovanju sveta se je razvijalo predvsem rabno znanje. Pomanjkljivost tradicionalne šole je bila, da nas niti rabnega niti odnosnega znanja ni naučila ustvarjalno uporabljati. Te naloge usmerjeno izobraževanje ni rešilo, izobraževanje v postsocialistični tranziciji pa tudi še ne.

\section{Šolsko znตnje}

V politiki šole prevladuje $v$ šoli pragmatični koncept, ki nenehno preverja, ali so učinki zaželeni, pri nezaželenosti pa korigira postavljene cilje (Medveš, 1992:19) in izkazuje pripravljenost na obvladovanja negotovosti in protislovnosti šole. V javni šoli se znanje pojavi šele tedaj, ko ni več živo v nastajanju; ko njegove procesne, raziskovalne prvine otrpnejo v okamenele strukture ali pa ostanejo podrejene. Hitrejše proizvodnje znanja ne more biti brez prenosa v šolski kurikulum, ki upošteva tudi reševanje problemov.

Znanje je v različnem razmerju do duševne aktivnosti. Pasivno znanje, ki je nam odraslim najbolj znana kategorija, je rezultat nižjih psihičnih aktivnosti, aktivno znanje pa je rezultat višjih aktivnosti. Aristotelova teorija psihosocialnega razvoja dopušča glede na stopnje psihične aktivnosti ugotavljanje višje in nižje stopnje kulture. Šole skušajo zaposlovati učence celostno, na primer s projektno obliko dela. Učenci so zanjo bolj motivirani kot za druge načine dela, ker jim omogoča več lastne ustvarjalne ak- 


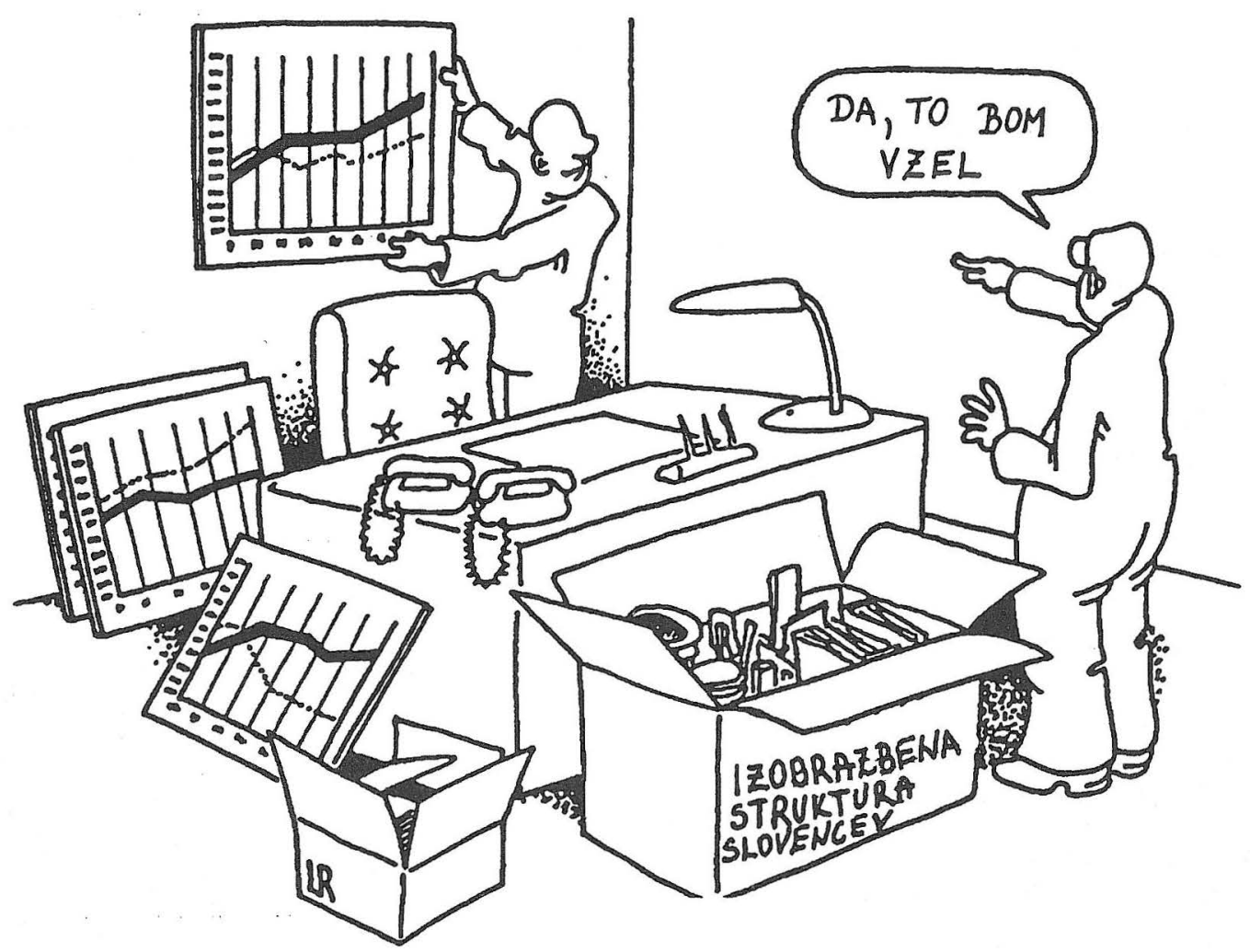

tivnosti in trajnejšo zapomnitev. Čim več vrst zakonitosti določeno znanje vsebuje, tem bolj celovito je. Odrasli se ne uči več za zalogo, njegovo znanje je že interdisciplinarno, ker vsebuje več vrst zakonitosti. Zaveda se tudi neodpravljivega in sproti nastajajočega neznanja, pa tudi hitre pozabljivosti.

V šoli se pogosto odprta struktura znanja zapre v idealno dogmatično formo. Učenec dobi vtis, da je takšno znanje dokončno. Učitelj se zaman trudi, da bi takšno poenostavljeno, neživljenjsko in okrnjeno znanje postalo učencem osnovna vrednota, ker to tudi njemu, kot odraslemu, ne pomeni. S takšnim znanjem se distancira od učencev, vzdržuje zunanji red in mir in dokazuje neznanje. Spominsko, ponovljivo znanje je lahko sredstvo za ustvarjalno znanje ali za kazensko discipliniranje učencev (npr. kadar naj se učenci česa sami naučijo iz knjige, prepišejo domačo nalogo, ponavljajo postopke ali operacije, ne da bi jih razumeli). Odrasli bi si morali, zlasti pri prenovi učnih načrtov, odgovoriti na vprašanje, kaj je živo in mrtvo v družinskih, šolskih, institucionalnih odnosih, v znanju in socializacijskih obrazcih in odpravljati to, kar je mrtvo.

Dilema usmerjenosti šole na povprečne učence ali na elito, ki zmore več, pomeni izbiro med spominskim in ustvarjalnim zna-

\footnotetext{
${ }^{4}$ Izraz kognitivna znanost je novejši. Sam termin je uvedel leta 1973 Longuet Higgins. Leta 1977 je začel izhajati časopis Cognitive Science. Kognitivna znanost se uveljavlja kot znanost, ki proučuje razmerja, ki jih inteligentna bitja vzpostavljajo z okoljem. Kognitivna znanost je sestavljena iz podpodročij: znanost o računalnikih (computational theory), filozofija, psihologija, nevrologija, lingvistika, antropologija. Več o tem glej v sestavku Scheerer, Eckart (1991): U susret povijesti kognitivne znanosti. V: Šoljan, N. Nikola, Kovačevič, Melita: Kognitivna znanost. Zagreb, Školske novine, str. $22-40$ in
}

njem. Usmerjeno izobraževanje ni odgovorilo na vprašanje, kakšno znanje potrebujemo za aktivni odnos do sveta in do sebe. Če želimo spremeniti svet in sebe, potrebujemo informacije o spremembah in kognitivno ${ }^{4}$ samokontrolo sprememb.

Znan je očitek, da šola ne nauči misliti. To ni povsem pravilno. Vsaka šola uči misliti, vsaj enoumno. Vendar je pomanjkljivosti enoumja, ki mu je bila prirejena politika polpreteklega obdobja, danes težko nadomestiti. Dejansko je nemir duha zaradi blokiranih meja znanja obstajal tudi v polpreteklem obdobju. Življenjskost znanju daje mišljenje, ki ni obremenjeno s "predsodki« (Bacon). Enoumje je bilo prevladujoči vzorec kolektivističnega socialnega učenja, ki je bil poenoten za odrasle in otro$\mathrm{ke}$, ni bil pa edini. Dopuščanje individualnosti in pluralizma interesov $^{5} \mathrm{v}$ samoupravnem sistemu je kazalo na določen kompromis pri vprašanju politično sistemske določenosti ali nedoločenosti človekovega bivanja. Slabost kapitalistične nedoločenosti je v tem, da vodi v eksistencialno praznino.

Večstransko mišljenje predpostavlja logično mišljenje, ki posamezniku ni prirojeno, temveč je pridobljeno z vajami v šoli ali pa šele s poklicnim delom. Le nekateri ljudje si ga oblikujejo-do 20. leta starosti, nekateri pa si ga sploh ne. Tudi sposobnost za

Greeno, G., James (1991): Nov pogled na prirodo mišljenja. V: Šoljan, N. Nikola, Kovačevič Melita: Kognitivna znanost. Zagreb, Školske novine, str. 233-251.

${ }^{5}$ Pluralizem kaže razumeti kot pot $\mathrm{k}$ holizmu. Pluralizem razumemo le politično glede na večstrankarski sistem, gre pa tudi za multikulturni, religiozni, gospodarski (privatizacija) in edukacijski pluralizem. Pediček (1990) je orisal ravni pluralnosti, od ontološke, spoznavnointerpretske in psihološke, svetovnonazorske, pedagoško-didaktične do antropološke ravni. 
posamezne logične operacije ni pri vseh enako razvita. Psihometrična raziskovanja so pokazala, da ljudje, ki imajo smisel za deduktivno sklepanje, nimajo nujno enakega smisla tudi za induktivno sklepanje in nasprotno. Vsi ljudje sklepamo na oba načina, vendar vsi ljudje tudi za logično mišljenje nimamo enakega smisla. Čeprav gre pri obeh operacijah za razmerje med posameznim in splošnim, pa dobi v novem veku indukcija pomen pridobivanja novega znanja. Te ugotovitve ustvarjajo pomisleke o vrednosti uniformnih testov znanja. Načelo »enako znanje za vse« je vprašljivo tudi s stališča lastnih potreb posameznika in lastnega dela, ki zahteva manj prilagajanja navzven in več inovativnosti kot pridobitno delo. Vendar nima »racionalne omejitve« le politična socializacija enakosti, ki v skrajni posledici onemogoči razvoj, temveč tudi neenakosti, ki vodi v čedalje večjo polarizacijo družbe. Odprto vprašanje je, kako je mogoče v tranziciji socializirati hkrati (ne)enakost in svobodo.

Učencem je treba s »scandalonom《 dati priložnost za presojanje in jih zaposliti z osebno dejavnostjo in izkušnjami. Šolsko znanje je še intelektualistično. Res pa je, da se ta zveza pri nekaterih predmetih uveljavlja laže kot pri drugih. V različnih kulturnih okoljih in šolah ocenjujejo znanje različno. Razlike so v tem, da nekateri iščejo znanje, drugi pa neznanje. To se dogaja $v$ jeziku sprejemanja in zavračanja. Po Pygmalionovem efektu oziroma po zakonu samouresničene prerokbe vemo, da učitelj z negativnimi spodbudami in s sankcijami pripravi učenca do tega, da ne zna. S tem v zvezi deluje Pygmalionov efekt podobno kot Murphyjevo načelo, »če gre kaj lahko narobe,...«, maligne spirale, preskušeni pa so tudi pozitivni učinki pozitivnega mišljenja. Prav zato, ker že s pričakovanji vplivamo na druge in na samega sebe, je tako pomembno, kakšna so. Uspeh učenca v šoli ${ }^{6}$ ni nujno povezan s sinergičnimi učinki interakcijske socializacije (sodelovanja učenca, učitelja in staršev), ker je lahko plod individualnega učenja učenca za lastne cilje.

V šoli ne obstaja niti samo spominsko-ponavljajoče niti samo sokratsko-enkratno znanje. Če je to že konstantni pojav, nastane vprašanje, kaj je v tem sploh novega. Nezaželenost sokratskega znanja je v tem, da vsebuje dvom v ustaljene oblike znanja, ki jih je mogoče relativno enostavno in hitro preverjati. Prednost sokratskega znanja pa je $\mathrm{v}$ tem, da vsebuje učeno nevednost in ne običajno ignoranco do nastajajočih oblik znanja. Misleči praktiki uporabljajo babiško modrost, ki vleče iz učenca to, kar že potencialno zna. Sokratsko metodo je laže uporabiti pri odraslih, ki imajo več potencialnega znanja, kot pri otrocih, čeprav je po drugi strani res, da so ti bolj radovedni. Prav sokratsko znanje omogoča odpiranje zgodovinskih alternativ.

Jasno je, da linearni napredek danes ni več mogoč. Sokratsko znanje je kot znanje o neznanju nov začetek in kot kritično evalviranje danih rešitev v smislu odgovora na (kantovsko) vprašanje, kaj lahko vem in v kaj lahko smiselno dvomim. S stališči skepticizma in agnosticizma lahko zanikamo upravičenost katere koli vrste znanja. Na prelomu stare paradigme se postavlja vprašanje, katero znanje je ustrezno za prihodnost informacijske družbe in katero ne. Znane so napovedi, da bo zaradi drugačnih vrednot velik del dosedanjega znanja postal neuporaben. Razkosano znanje nima takšne uporabnosti kot celovito, ker da le ustrezna količina zbranega znanja (ne prevelika in ne premajhna) novo ustvarjalno kakovost.

Tako kot bi učitelj laže ocenjeval vrednost znanja učencev, bi

\footnotetext{
${ }^{6}$ Uspeh kot neproblematično merilo učenja in dela je le tedaj »brez tveganja«, če ga razumemo kot pozitivno energijo, mišljenje in čustvovanje, ne glede na zunanje razmere. Kakor hitro pa življenje podredimo konkurenčnemu boju za preživetje, je naše učenje izpostavljeno nenehnemu tveganju, da nas okolica ne bo priznala. Umetnost gotovosti v negotovosti je $\mathrm{v}$ brezpogojnosti sobivanja.
}

se tudi učenec laže ocenjeval, če bi oba poznala načine njegovega konstituiranja in njegovo bipolarno strukturo. Po prvem merilu se ravna sodobni učitelj, ki ve, kateri tip zaznavanja oziroma sprejemanja znanja pri učencu prevladuje, akustični ali vizualni, in mu ga zato ustrezno posreduje. Po drugem merilu je pomembno, kako določeno znanje nastaja v sami znanosti: po induktivno-eksperimentalni metodi kot v novoveški znanosti ali deduktivno-razumski kot v staroveški.

\section{Spremenjene razmere in polihięnosecializecijske dileme}

Vsi smo izpostavljeni izzivom »pospeševalnega sindroma« (Russell, 1993), ki postaja zakon življenja. Ta zakon pomeni, da ustvarjalnost rodi ustvarjalnost, ki se razvija s pozitivno povratno informacijo. Odrasli so v vlogi posrednih proizvajalcev. Svoje izkušnje in znanje prenašajo na mladino. Današnja kriza poraja nove nevarnosti in priložnosti. Človek spoznava, da lahko ohranja svojo stabilnost v spremembah le tedaj, če ni le akcijsko, temveč tudi kontemplativno bitje. Socializacija za in skozi politični aktivizem, ki jo je uresničeval socializem, je spodbudila človeško energijo za previsoko postavljene cilje. Temu je sledilo razočaranje, ki zahteva z iskanjem ravnotežja med racionalnim in iracionalnem v političnem človeku redefiniranje in ponovno osmislitev politične socializacije, s tem pa tudi med že doseženim, realnim in mogočim, še nedoseženim v politični aktivnosti.

Odrasli zaradi naučenega znanja pogosto ne vidimo vrednosti stare modrosti, ki bi jim pomagala iskati življenjsko ravnotežje in se braniti pred vsakdanjimi stresi. Samoosvoboditev (oziroma samorealizacija po Maslowu) pritiskov od zunaj, ki povzročajo strese, je bila doslej izjema, v prihodnje pa naj bi postala pravilo. Človek skuša sedaj svojo zunanjo tehnično revolucijo osmisliti z notranjo. Cilj vseživljenjske edukacije je opismenjevati posameznika, ki naj bi znal pridobljeno znanje uporabiti v vsakdanjem življenju in razumel kompleksno soodvisnost med pojavi. Multifunkcionalno izobražen posameznik se laže in bolj odgovorno spoprijema s problemi postindustrijske družbe.

Posameznik spoznava samega sebe v svoji (ne)spremenljivosti, (ne)ponovljivosti in (ne)presežnosti vse življenje. To spoznanje ni zvedljivo na družbene in politične ustanove, sredstva javnega obveščanja, na norme ali lastni jaz, ki se postmoderno členi (oziroma decentralizira), in na kulturne tradicije. Človek kot bipolarno bitje (moški in ženska, leva in desna polovica možganov) se tudi spoznava bipolarno. Ker napovedujejo, da bo 21 . stoletje doba teorije in »orientacije« (Hribar, 1996:161) bomo skušali osvetliti pomen formalno (šolsko) in neformalno pridobljenega znanja odraslih za izzive nove dobe.

Danes prevladuje $\mathrm{v}$ razvitem svetu prefigurativno obdobje kulture, v katerem mladi učijo odrasle. To pomeni, da je že primarna socializacija dvosmeren proces, $v$ katerem ne postaja otrok le osebnost po meri sveta odraslih, temveč tudi odrasli starši v sebi znova odkrivajo otroka, $s$ tem, da otroci vplivajo nanje. Ljudje različne starosti komunicirajo med seboj z različnimi, neenakimi stopnjami in oblikami kulturnega kapitala, ki povzroča neenakomeren razvoj med državami in regijami v državi. To vodi do napetosti in protislovij, za katere ne vemo, ali so razrešljiva ali ne. Če se že kulturnega kapitala ne da izenačiti, v kar je iluzorično verjel socialistični sistem, si zamudniki postavljajo vprašanje, $v$ čem in kako se da nadomestiti zamujeno, prvi v konkurenci pa se sprašujejo, kako ohraniti pridobljeno prednost.

Vzhodna in del centralne Evrope doživlja danes tranzicijo iz socializma $\mathrm{v}$ kapitalizem. S propadom socializma so propadle tu- 
di stare oblike socialnosti in solidarnosti, nove pa šele komaj opazno nastajajo. Reprivatizacija $\mathrm{z}$ denacionalizacijo poglablja individualizacijo in postavlja odrasle pred zahtevo resocializacije, mlade pa pred dejstvo drugačne socializacije. Zato so vedno večje izobraževalne zahteve obenem tudi drugačne izobraževalne zahteve. Enosmerno sistemska (politična) socializacije je postala večsmerno razpršena. Nastaja nova demokratična politična kultura, v nestabilnem demokratičnem političnem sistemu. Gre za preusmeritev družboslovnega znanja iz monopolne paradigme k pluralni paradigmi.

Naravoslovno znanje je že zaradi krize onesnaževanja preusmerjeno k holistični paradigmi. Holizem že zaradi integracije delov v celoto predpostavlja pluralizem. Čeprav se tudi pri nas postopno uveljavljajo holistične metode in tehnike učenja, pa se zaradi pomanjkanja dialektičnega, kibernetičnega oziroma kritičnega mišljenja veliko teže uveljavlja večsmerno mišljenje in ustvarjalno reševanje problemov. Učenje najpogosteje povezujemo z znanjem, vendar je očitna tudi povezava $\mathrm{z}$ mišljenjem in $\mathrm{s}$ socializacijo. Socializacija je glede na prisvajanje znanja o socialnih odnosih zanje že sama po sebi socialno učenje. Z vsakim signifikativnim učenjem pa se $\mathrm{z}$ učenjem prestrukturira tudi določena organizacija znanja. Z mišljenjem dejansko znanje prestrukturiramo za nove socialne vzorce, hkrati pa spreminjamo tudi miselne vzorce. Ker se hkrati s spreminjanjem sveta spreminjamo tudi sami, se s tem spreminjajo tudi socialni in miselni obrazci. V enostavni reprodukciji predmoderne, predindustrijske družbe je zadoščalo le pasivno, spominsko znanje. Nepričakovane, hitre spremembe običajno pahnejo večino $\mathrm{v}$ krizo $\mathrm{z}$ občutkom, da se ne da ničesar napraviti, kar pomeni pasivizacijo, nostalgijo in apatijo z (začasno) izgubo življenjskega smisla. To se je zgodilo tudi v obdobju tranzicije, s prehodom v postindustrijski, mrežno informacijski način proizvodnje in komunikacije.

Tako so mladina in odrasli postavljeni pred vprašanje, kako biti, kar si, kljub hitrim spremembam in prav zaradi njih. V industrijski družbi je človek postal problematičen glede na to, kar ni. To pa ni dobro zaradi vedno večjega dualizma v njem samem oziroma duhovnega zaostajanja zaradi vedno večjega tehnološkega napredka. Ker tehnološki napredek, zlasti v državah, ki uvažajo tujo tehnologijo, ni prilagojen sedanji nacionalni kulturi in njeni stopnji gospodarske razvitosti, se pojavljata dezorientacija in kaos. Politika »velikih skokov«, poskusov dohitevanja zamujenega, iskanja prednosti v zaostajanju, ad hoc uvajanja računalnikov v ustanove itd, je že pokazala svoje slabe strani, ker je temeljila na enodimenzionalnem mišljenju.

Nismo se vprašali po kakovostno drugačni politični socializaciji in z njo vred po drugačni državniški politiki. Ker zlasti tisti, ki vodijo državo kot »ujetniki preteklosti« (Bučarjeva sintagma), niso spremenili svojega šolanega mišljenja, se nam zdi nova demokracija v samostojni državi Sloveniji podobna »novemu vinu v starih mehovih«. Že stari Grki so vedeli, da se neizživeta preteklost vrača kot usoda. Vedeli so tudi to, da kraljevske poti k znanju ni, niso pa mogli vedeti, da ni bližnjic k svobodi vseh. Že večkrat smo hoteli revolucionarno in radikalno pretrgati s preteklostjo tudi zato, ker nismo našli pozitivnih vsebin v negativni, meščansko ali socialističnototalitarni formi. Pri tem se nismo zavedali, da nekrofilni, neživljenjski elementi naše kulture izvirajo od drugod in da je totalitarna forma že posledica. Gre za to, da nespravljiva izključevalnost našega in tujega pomeni izključevalnost in nespravljivost $\mathrm{v}$ nas samih.

Zelo pomembno je, ali se politično socializira (ponavlja) diskontinuiran, avtoritarni, separatni, dezintegrirajoč in v skrajni posledici negativistično avtoritaren model kulture ali pa demokratični, pluralen integrativen model, $\mathrm{z}$ upoštevanjem pozitivnih vsebin tradicije za prihodnost. O kakovosti življenja razmišljamo predvsem v razmerju med kakovostjo delovnega in prostega časa, ne pa v zvezi z razlikovanjem kakovosti modelov politične socializacije.

Od izbire enega od teh dveh modelov je odvisna pozitivna ali negativna samopodoba Slovencev in možnost ali nemožnost njihovega preživetja v nacionalni državi. Slovenci sicer vemo, da moramo vstopiti v Evropsko skupnost vsaj kot pridruženi člani, ne moremo pa vedeti, kaj ta vstop posledično pomeni glede kakovosti politične socializacije in kakovosti življenja.

$\mathrm{Ni}$ jasno, ali smo pripravljeni opustiti monopolne modele socializacije in jih nadomestiti z multifunkcionalnimi. Po eni strani je zaradi izredne moči primarne socializacije pridobivanje določenih znanj, spretnosti in veščin »že v vrtcu prepozno«, po drugi strani pa ni po načelih »napraviti pravočasno (just in time) in »nič ni nemogoče « za nadomeščanje zamujenega škoda nobenega časa. Glede na tezo, da je človek edini neizčrpljiv vir energije v svetu, so naše zmogljivosti možganov večje, kot smo jih navajeni izkoriščati (5-10\%), po drugi strani pa že zlorabljanje dosedanjega znanja v zvezi $\mathrm{z}$ onesnaževanjem vodi $\mathrm{k}$ svarilom, da ni etično in smotrno napraviti vsega, kar se da napraviti. Človek ni le zgodovinsko gledano čedalje manj prožno bitje, (ker je čedalje bolj determiniran $\mathrm{z}$ minulim delom prejšnjih generacij), temveč je tudi bitje s čedalje bolj potrebnim smotrom in smislom. Zato pri odločanju o usodi Slovencev ni zadosten uveljavljen pragmatični model mišljenja za preprečevanje neugodnih posledic s prilagajanjem, ki samo podpira že sedanji pasivno prilagoditveni model socializacije, temveč je potreben interakcijski model, ki ga naša kultura, pogosto poistovetena $\mathrm{z}$ literarnim humanizmom, ne vsebuje.

Socializacijske dileme izhajajo iz notranjega razlikovanja znanja na kulturno - humano in tehnološko - obvladujoče znanje. Dolgoročno pomeni kulturno humano znanje v nacionalnem smislu primerljivo prednost pred tehnološkim. Tako so slovenski intelektualci ustvarili trdno kulturno podlago za politično samostojnost slovenske države, večinski del prebivalstva pa kaže kulturno zanemarjenost zaradi pretirane skrbi oziroma »nevroticizma« (Musekov izraz) za vsakdanje preživetje in nezaupanja v državne ustanove. Pri nas prevladujeta negativno mišljenje in energija, spontano učenje pa nastaja iz pozitivne naravnanosti, odprtosti, samozavesti (Beaver, 1995). Če pred samimi seboj veljamo kot kulturni narod, bi moralo biti obdobje razvoja kulture še pred nami kot plod skupnih kulturnih, gospodarskih in političnih dosežkov. Manjka nam veselje do življenja (fr. joie de vivre) in z njim vesela znanost. Izobraževanje odraslih relektira kulturne razlike in podobnosti. Bistvena razlika med slovensko preteklostjo in sedanjostjo je, da smo se nekoč učili, kako se podrejati, sedaj pa se učimo, kako delati neodvisno in kako naj vzamemo usodo v svoje roke (Krajnc, 1995).

Dejstvo je, da šola daje premalo celostnega znanja za poklicno delo in osebni razvoj. Vse učiteljevo delo ${ }^{7}$ je podrejeno preverljivemu znanju, od osnovne šole do univerze. Tudi učitelj je (bil) predmet vzgoje, ker ni le od njegove izbire metod in oblik vzgojnoizobraževalnega dela odvisno, kakšne odnose in vrednote $z$ učenci sooblikuje. Razkosano znanje ni sestavina duhovne kulture, je pa predmet strankarsko razdeljene politike. Politiki kot boju za oblast ustreza obvladujoče znanje, skupnostna politika pa ni mogoča brez vživljanja v potrebe drugih; podobno velja za edu-

\footnotetext{
${ }^{7}$ Dober učitelj ni le tisti, ki dobro razlikuje (npr. med avtoritarnostjo in avtonomijo, med normami in vestjo, med učenjem sebe in učenjem drugih), temveč tudi tisti, ki ve, da bo v konkurenčnem boju za pridobivanje novega znanja, presežen. Dokler hoče biti dober učitelj, mora biti bolj radoveden kot učenec.
} 
kacijo, ki ne more postati obči interes, dokler je sredstvo neupravičene, a legalne selektivnosti.

Ker človek ni le racionalno, temveč tudi iracionalno bitje, razlikujemo med obvladujočim in empatičnim znanjem, pa tudi med linearno-analitičnim in večstransko sintetičnim mišljenjem. Vsako znanje je določen način obvladovanja dejanskosti že zato, ker je neločljivo povezano z močjo. Vprašanje je le, ali želimo obvladovati zunanji ali lastni notranji svet. Obvladovanje notranjega, psihičnega sveta ni mogoče brez vživljanja v svoje osebne potrebe in potrebe drugih. Šola učence premalo poučuje o tem, kako upravljati in obvladovati notranji svet. Zanimivo je, da to področje običajno tudi ne spada k poklicnemu usposabljanju in izpopolnjevanju. Pri odraslih programski cilji izpopolnjevanja in usposabljajo določajo, katero znanje je bistveno. Pragmatično usmerjeno usposabljanje je zgolj dopolnilno in se ne razlikuje bistveno od zaokroženih paketov znanja, ki ga še vedno posredujeta osnovna in srednja šola. Dežele v tranziciji ne poznajo nikakršnega političnega usposabljanja. Zanimivo pa je, da ga je izvajala komunistična partija.

Prav tako je okrnjeno usposabljanje za zakonsko zvezo in družinsko življenje, čeprav to področje sodi med najtežje in najbolj občutljive življenjske oblike. Slaba in nesistematična politika družine ne kaže le na pomanjkanje znanja o družini in odpovedovanje pedagogike družine ${ }^{8}$, temveč tudi za določeno nepriznavanje družine za osnovno celico družbe. Znanje za vzgojo najbolj obvladujejo vzgojitelji in učitelji. Najmanj ga obvladujejo starši, ki so odgovorni za primarno socializacijo, ker se za svojo vlogo izobrazijo pretežno $\mathrm{z}$ uporabo priročnikov ali na tečajih. Ne le za družino, marveč tudi za našo šolo je pomembno, ali naj dobijo starši večjo vlogo pri vzgoji. Nadzor staršev nad delom šole je pri nas manjši kot v tujini.

\section{Sklep}

V postsocialističnih državah se uveljavlja politika, ki izhaja iz interesov kapitala, se zavzema za večjo tekmovalnost, storilnost, diferenciranost razvojnih poti, svobodno izbiro šol in programov, veliko selektivnost, večjo kvaliteto znanja oziroma prilagojenost šolanja procesom družbene reprodukcije. Takšna politika je spodbuda za drugačen, fleksibilnejši proces socializacije, ki omogoča uspešnost le tistim posameznikom, ki si znajo poiskati širši krog komunikacije in sodelovanja tudi v političnem delovanju. Ti ne le laže dobijo zaposlitev, temveč si tudi poiščejo novo, če staro izgubijo.

dr. Bogomir Novak

raziskovalec na Pedagoškem inštitutu Univerze v Ljubljani

\section{Liferghure}

Beaver Diana (1995): Krog odličnosti. Knjiga o hitrem in nenapornem učenju. Ljubljana, Julija Pergar

Glaser William (1996): Kontrolna teorija za managerje. Ljubljana. Hafner Fink (1993): Uspešnost utrjevanja demokracije na Slovenskem: nekateri kazalci. V: Hafner Fink Danica (1993): Problemi konsolidacije demokracije. Politološki dnevi Ankaran '93. 28. in 29. maj 1993. Slovensko politološko društvo. Zbornik referatov, str. 19-36.

Krajnc Ana (1995): The Enlightenment Movement Adult Education and National Identity. In: Poeggeler Franz: National Identity and Adult Education. Challenge and Risk. Frankfurt am Main, Peter Lang, str. 193-209.

Mangabeira Ungar Roberto (1989): Znanje i politika. Zagreb, Globus.

Medveš Zdenko (1990): Se politika umika iz šole ali šola iz politike? V: Šola $\mathrm{v}$ političnem pluralizmu. Zbornik. Ljubljana, Marksisitični center, str. 27-36.

Medveš Zdenko (1992): Aktualnost klasičnega razumevanja doktrine v sodobni šoli. V: Macura Dušan (ured.): Šolska doktrina na sodobni preizkušnji. Ljubljana, Enajsta univerza, str. 12-29.

Pediček Franc (1990): Pluralizem v polju vzgoje in izobraževanja. V: Pediček Franc (ured. et al.): Šola v političnem pluralizmu. Zbornik. Ljubljana, Marksistični center, str. 9-17.

Peretti Andre de (1987): Pour une école plurielle. Paris, Larousse.

Russell Peter (1993): Sedaj. Konec časa in začetek sedanjosti. Ljubljana, Alpha center.

\footnotetext{
${ }^{8}$ Pomanjkanje na tem področju skuša odpraviti dr. Angelca Žerovnik s knjižico Pedagogika družinskega ognjišča. Ljubljana, PI. Knjižica je v tisku.
} 